\title{
Pain and Discomfort Associated With Initial Alignment with Three Different Archwires-A Clinical Study
}

\author{
Dr.Anand Ambekar
}

\section{Introduction :}

Pain and discomfort are common place after insertion of an initial archwire during orthodontics ${ }^{1}$ and are reported at some stage during treatment by $91 \%$ of patients and following each appointment by $39 \%$. $^{2}$ The level of pain reported after archwire placement is believed to be greater and more prolonged than that following extraction of teeth. ${ }^{1}$ Discomfort peaks on the morning after placement of an archwire remained at this level for 2 to 3 days before abating at 5 to 6 days. ${ }^{1}$ The fear of potential pain related to treatment affects the uptake of orthodontic care. ${ }^{3}$ Furthermore, treatment discontinuation ${ }^{4}$ and poor compliance ${ }^{5}$ have been attributed to discomfort experienced in the early stages of appliance therapy.

Pain may be elicited by heavy pressure placed on the tooth with an instrument or by normal mastication, or it may arise spontaneously ${ }^{6}$; pain is known to be influenced by psychological, sociocultural, and environmental factors, making objective evaluation difficult. The experience of pain is measured indirectly, and the visual analog scale (VAS) is the most reliable method of measuring pain perception. ${ }^{7-10}$ Nonlinear relationships have been shown between pain experienced after initial archwire placement and archwire material and age; social class; degree of force applied; dental arch relationships; and dental crowding. ${ }^{11-15}$ It is not surprising that the use of preemptive and postoperative analgesia has been shown to reduce pain scores. ${ }^{8}$

The present study is intended to test whether any significant difference in the pain and discomfort experience could be found during initial alignment with three initial archwires, i.e. 0.0175 multisranded stainless steel archwire, $0.018 \mathrm{Cu}-\mathrm{Niti}$ and $0.018 \mathrm{Niti}$.

Ideally, archwires are designed to move teeth with light and continuous forces. Such force reduces the potential for patient discomfort, tissue hyalinization and undermining resorption. When force is applied, the archwire should behave elastically over a period of weeks to months. Keeping these wire characteristics in mind, research work was pursued by orthodontists.

\section{AIMS AND OBJECTIVES:}

1 To investigate the amount of pain and discomfort experienced by the patient during the alignment phase of treatment.

\section{Materials And Methods:}

Nickel Titanium has made a revolution in the field of orthodontics. Utility of the elastic properties of Nickel Titanium arch wires has minimized the tedious job of wire bending.

The present study was conducted to further understand the clinical behavior of Nickel titanium, copper Nickel Titanium and multistranded stainless steel wires in the initial alignment.

Armamentarium used in the clinical study:

a. Bracket system $-0.022 \times 0.028$ " MBT preadjusted bracket system (Ormco) (Victory series).

b. $\quad$ Arch wires (preformed, round)

$$
\begin{array}{ll}
- & 0.018 " \\
- & 0.018 " \text { Nickel Titanium (Libral) } \\
\hline & 0.0175 " \text { multistranded stainless steel (Libral) }
\end{array}
$$

The wire samples under study were divided into three groups of 10 patients each.

\section{METHOD OF STUDY:}

Patients were randomly selected from the daily OPD of Department of Orthodontics and Dentofacial Orthopedics, P.M.N.M. Dental College and Hospital, Bagalkot. Pre-treatment records as mentioned earlier were taken. The patients were referred for oral prophylaxis, then patients were send for extraction of first premolars. After that bands were prepared on molars and 0.022" MBT preadjusted appliance was bonded according MBT prescription (Ormco).

The 3 arch wire types were randomly allocated to patients according to predetermined random allocation scheme. The records were taken at the interval of $1 \mathrm{hr}, 5^{\text {th }} \mathrm{hr}, 10^{\text {th }} \mathrm{hr} ., 24^{\text {th }} \mathrm{hr}$. and $2^{\text {nd }}$ day to $6^{\text {th }}$ day. 
PATIENT NAME

OPD NO.

AGE :

ARCH WIRE :

QUESTIONNAIRE

1. Is the appliance painful?

Yes/No

2. If yes

a. On the day of commencement of treatment how much pain you felt after

1 hour

5 hour :

10 hour :

b. $2^{\text {nd }}$ day

24 hour :

c. $3^{\text {rd }}$ day

d. $4^{\text {th }}$ day

e. $5^{\text {th }}$ day

f. $6^{\text {th }}$ day

g. $7^{\text {th }}$ day

3. Are you comfortable with the appliance?

Yes/No

4. Do you feel pressure on your teeth?

Yes/No

5. Are you feeling sensation during orthodontic treatment? Yes/No

6. Any difficulty during mastication?

Yes/No

GRADING

$$
\begin{aligned}
& 0=\text { Not at all } \\
& 1=\text { Very little } \\
& 2=\text { Much } \\
& 3=\text { Very much } \\
& \text { From, Hans Sergl (Am. J. Orthod., 1998) }
\end{aligned}
$$

\section{STATISTICAL ANALYSIS}

Various clinical parameters were graded in the form of scores. Mean crowding score and pain and discomfort score was determined and compared between three different types of wires by One-way ANOVA followed by Studentized Range Test for multiple comparison. Categorical data was analyzed by Chi-square test.

\section{Results And Observations:}

\begin{tabular}{|c|c|c|c|c|c|c|c|c|}
\hline & Group I mean & Group II mean & $\begin{array}{l}\text { Group III } \\
\text { mean }\end{array}$ & F-value & P-value & \multicolumn{3}{|c|}{$\begin{array}{l}\text { Difference between groups } \\
\text { I-II I-III II-III }\end{array}$} \\
\hline $\begin{array}{l}1^{\text {st }} \\
\text { hour }\end{array}$ & $\begin{array}{c}1.6+0.84 \\
-\end{array}$ & $\begin{array}{c}2.1+0.57 \\
-\end{array}$ & $\begin{array}{c}2.0+0.94 \\
-\end{array}$ & $\mathrm{F}=1.09$ & $\mathrm{P}=0.35$ & NS & NS & $\mathrm{NS}$ \\
\hline $\begin{array}{l}5^{\text {th }} \\
\text { hour }\end{array}$ & $\begin{array}{c}1.9+0.74 \\
-\end{array}$ & $\begin{array}{c}2.1+0.57 \\
-\end{array}$ & $\begin{array}{c}2.3+0.82 \\
-\end{array}$ & $\mathrm{F}=0.78$ & $\mathrm{P}=0.45$ & NS & NS & NS \\
\hline $\begin{array}{l}10^{\text {th }} \\
\text { hour }\end{array}$ & $\begin{array}{c}2.0+0.00 \\
-\end{array}$ & $\begin{array}{c}1.7+0.67 \\
-\end{array}$ & $\begin{array}{c}2.5+0.71 \\
-\end{array}$ & $\mathrm{F}=5.13$ & $\mathrm{P}=0.01$ & NS & NS & $\mathrm{P}<0.05$ \\
\hline $\begin{array}{l}24^{\text {th }} \\
\text { hour }\end{array}$ & $\begin{array}{c}2.0+0.00 \\
- \\
\end{array}$ & $\begin{array}{c}1.5+0.85 \\
- \\
\end{array}$ & $\begin{array}{c}2.5+0.71 \\
- \\
\end{array}$ & $\mathrm{F}=6.14$ & $\mathrm{P}=0.01$ & NS & NS & $\mathrm{P}<0.01$ \\
\hline $2^{\text {nd }}$ day & $\begin{array}{c}2.0+0.00 \\
- \\
\end{array}$ & $\begin{array}{c}1.5+0.53 \\
- \\
\end{array}$ & $\begin{array}{c}2.5+0.71 \\
- \\
\end{array}$ & $\mathrm{F}=9.64$ & $\mathrm{P}=0.01$ & NS & NS & $\mathrm{P}<0.01$ \\
\hline $3^{\text {rd }}$ day & $\begin{array}{c}1.8+0.42 \\
-\end{array}$ & $\begin{array}{c}1.3+0.82 \\
-\end{array}$ & $\begin{array}{c}2.2+0.79 \\
-\end{array}$ & $\mathrm{F}=4.13$ & $\mathrm{P}=0.03$ & NS & NS & $\mathrm{P}<0.01$ \\
\hline $4^{\text {th }}$ day & $\begin{array}{c}1.4+0.52 \\
-\end{array}$ & $\begin{array}{c}1.0+0.67 \\
-\end{array}$ & $\begin{array}{c}1.2+0.52 \\
-\end{array}$ & $\mathrm{F}=2.86$ & $\mathrm{P}=0.07$ & NS & NS & NS \\
\hline $5^{\text {th }}$ day & $\begin{array}{c}1.0+0.00 \\
-\end{array}$ & $\begin{array}{c}07+0.82 \\
-\end{array}$ & $\begin{array}{c}1.2+0.79 \\
-\end{array}$ & $\mathrm{F}=1.46$ & $\mathrm{P}=0.25$ & NS & NS & NS \\
\hline $6^{\text {th }}$ day & $\begin{array}{c}0.8+0.42 \\
- \\
\end{array}$ & $\begin{array}{c}0.6+0.70 \\
-\end{array}$ & $\begin{array}{c}0.8+0.42 \\
- \\
\end{array}$ & $\mathrm{F}=0.47$ & $\mathrm{P}=0.62$ & NS & NS & NS \\
\hline $7^{\text {th }}$ day & $\begin{array}{c}0.6+0.52 \\
-\end{array}$ & $\begin{array}{c}0.2+0.42 \\
-\end{array}$ & $\begin{array}{c}0.7+0.84 \\
- \\
\end{array}$ & $\mathrm{F}=3.098$ & $\mathrm{P}=0.06$ & NS & NS & NS \\
\hline
\end{tabular}

Three archwires of different materials are compared to test the hypotheses that (1) there is no difference in the pain experience during the week following initial placement of appliance. The changes at each interval were noted and statistical evaluation done.(table I).

Table 1: comparison of pain scores \{mean\} between three arch wires

GROUP I- 0.0175 MSS 


\section{GROUPII- $0.018 \mathrm{Cu}$ NiTi.}

GROUP III- 0.018 NiTi.

Table I shows the pain scores between 3 wires at each time interval. The pain level at $1^{\text {st }}$ hour and $5^{\text {th }}$ hour was almost same with multistranded stainless steel, CuNiti andNiTi wires and they are 1.9, 2.1 and 2.3 respectively(graph 1). There was no statistically significant difference found between them. But at $10^{\text {th }}$ hour to $3^{\text {rd }}$ day the pain levels were increased with multistranded stainless steel and NiTI wires. The pain levels were low with CuNiTi archwire. The pain levels were2, 1.5 and 2.5 with MSS ,CuNiTi and NiTi wires respectively. Statistically significant difference was found between CuNiTi and NiTi wires ( $\mathrm{P}<0.05,0.01$ ). There was no statistically significant difference was found between MSS and CuNiTi archwires and MSS and NiTi wires (graph 2 ). From $4^{\text {th }}$ day to $7^{\text {th }}$ day the pain levels were decreased progressively for all wires and there was no statistically significant difference was found between them (graph 3 )

GRAPH 1 : PAIN

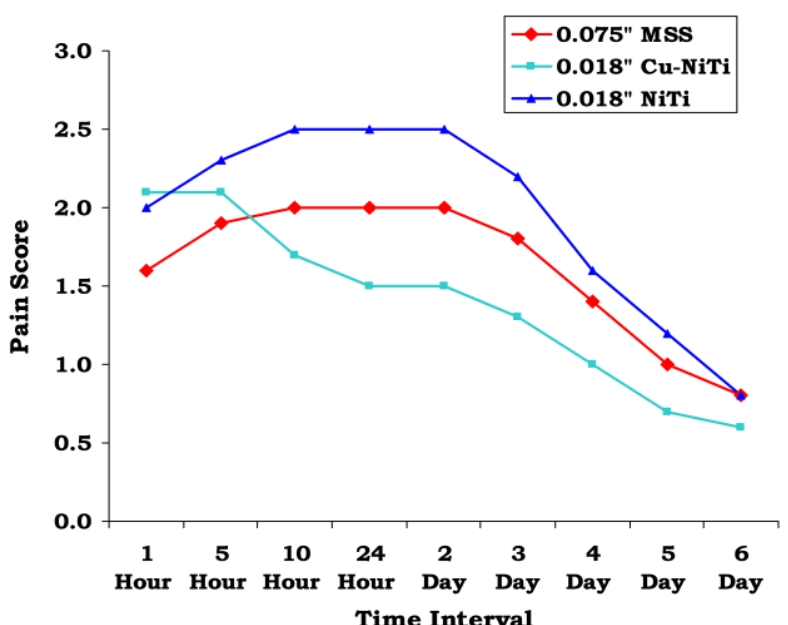

GRAPH 3 : PRESSURE

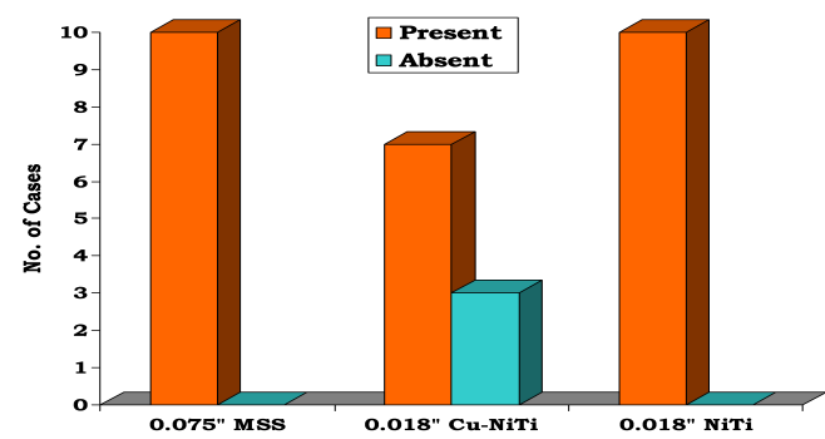


GRAPH 2 : APPLICATION PAIN

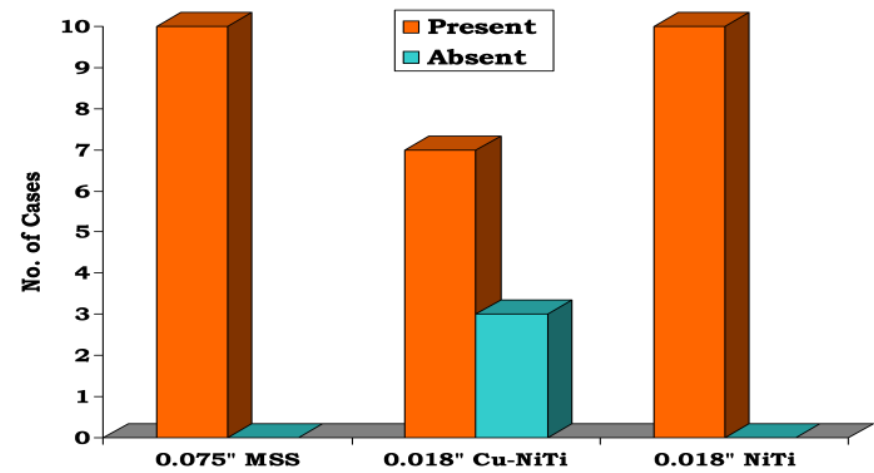

\section{Conclusion .}

Pain and discomfort index demonstrated that, pain associated with copper NiTi was less as compared to multistranded stainless steel and NiTi archwire.

\section{Bibliography}

[1]. Jones, M. and C. Chan . The pain and discomfort experienced during orthodontic treatment: a randomized controlled clinical trial of two initial aligning arch wires. Am J Orthod Dentofacial Orthop 1992. 102:373-381.

[2]. Lew, K. K. Attitudes and perceptions of adults towards orthodontic treatment in an Asian community. Community Dent Oral Epidemiol 1993. 21:31-35.

[3]. Bos, A., J. Hoogstraten, and B. Prahl-Anderson. Towards a comprehensive model for the study of compliance in orthodontics. Eur J Orthod 2005. 27:296-301.

[4]. Patel, V. Non-completion of active orthodontic treatment. Br J Orthod 1992. 19:47-54

[5]. Sergl, H. G. , U. Klages, and A. Zentner. Functional and social discomfort during orthodontic treatment: effects on compliance and prediction of patients' adaptation by personality variables. Eur J Orthod 2000 $22: 307-315$.

[6]. Burstone, C. J. Biomechanics of tooth movement. In: Krause BS, ed. Vistas in Orthodontics. Philadelphia: Lea \& Febiger; 1964:197-213

[7]. Otasevic, M. , F. B. Naini , D. S. Gill, and R. T. Lee . Prospective randomized clinical trial comparing the effects of a masticatory bite wafer and avoidance of hard food on pain associated with initial orthodontic tooth movement. Am J Orthod Dentofacial Orthop 2006. 130:e9-e15.

[8]. Polat, O. and A. I. Karaman . Pain control during fixed orthodontic appliance therapy. Angle Orthod 2005. $75: 210-215$.

[9]. Harradine, N. W. Self-ligating brackets: where are we now? J Orthod 2003. 30:262-273

[10]. Miles, P. G. , R. J. Weyant, and L. Rustveld. A clinical trial of Damon 2 vs conventional twin brackets during initial alignment. Angle Orthod 2006. 76:480-485.

[11]. Andreasen G.F. and Morrow R.E. (1978) : "Laboratory and clinical analyses of nitNitinol wire". Am. J. Ortorthod. ; 73(2) : 142-151.

[12]. Fernandes L.M., Ogaard B. and Skoglund L. (1998): "Pain and discomfort experienced after placement of a conventional or a superelastic NiTi aligning archwire. A randomized clinical trial”. J. Orofac. Orthop. ; 59(6) 331-339.

[13]. Gil F.J. and Planell J.A. (1989) : "Effect of copper addition on the superelastic behavior of NiTi shape memory alloys for orthodontic applications". Dept. Of Materials Sciences and Metallurgical Engineering, University Politecnica Catalunya, Diagonal : 647 (Abstract)

[14]. Andreasen G.F. and Wass K. (1985) : “A review of superelastic and thermodynamic nitinol wire”. Quint. Int. ; 9: 623-626.

[15]. Andreasen G.F., Hileman H. and Krell D. (1985) : "Stiffness changes in thermodynamic nitinol with increasing temperature". Angle Orthod. ; $55: 120-126$. 